\begin{tabular}{ll}
\hline Homepage: http://jusami.batan.go.id & Jurnal Sains Materi Indonesia \\
& $\begin{array}{l}\text { Akreditasi LIPI } \\
\text { No.: 602/AU3/P2MI-LIPI/03/2015 } \\
\text { Tanggal 15 April 2015 } \\
\text { ISSN : 1411-1098 }\end{array}$ \\
\hline
\end{tabular}

\title{
PENGUJIAN KANDUNGAN LOGAM RENIK DAN KUALITAS GARAM ANEKA PANGAN HASIL PROSES KRISTALISASI LARUTAN BRINE
}

\author{
Eriawan Rismana dan Zainuddin \\ Pusat Teknologi Farmasi dan Medika - BPPT \\ Kawasan Puspiptek, Serpong 15314, Tangerang Selatan \\ E-mail : eriawan.rismana@bppt.go.id
}

Diterima: 12 Mei 2017

Diperbaiki: 10 Agustus 2017

Disetujui: 25 Oktober 2017

\begin{abstract}
ABSTRAK
PENGUJIAN KANDUNGAN LOGAM RENIK DAN KUALITAS GARAM ANEKA PANGAN HASIL PROSES KRISTALISASI LARUTAN BRINE. Garam aneka pangan merupakan salah satu jenis garam yang masih di impor. Untuk substitusi impor maka diperlukan pengembangan teknologi proses produksi garam tersebut di dalam negeri. Dalam penelitian ini telah dilakukan kajian produksi garam aneka pangan menggunakan proses kristalisasi dengan bahan baku larutan brine sisa produksi garam farmasi. Hasil uji garam aneka pangan secara uji kualitatif meliputi reaksi nyala, uji kation natrium dan anion klorida, uji kelarutan, pengamatan bentuk kristal secara mikroskopi dan pola difraktogram XRD menunjukkan hasil yang sama dengan data MSDS $\mathrm{NaCl}$. Sedangkan pengujian kandungan logam renik dan kualitas pada garam tersebut menunjukkan bahwa produk telah memenuhi pesyaratan kualitas antara lain kandungan $\mathrm{NaCl}$, magnesium, kalsium, sulfat, air, dan logam berat sesuai Peraturan Menteri Perindustrian No. 88/M-IND/PER/10/2014.
\end{abstract}

Kata Kunci : Garam aneka pangan, Kristalisasi, Larutan brine, Karakterisasi, Kualitas

\begin{abstract}
DETERMINATION OF TRACE METAL CONTENTS AND QUALITY OF FOOD GRADE SALT PRODUCED BY CRYSTALLIZATION PROCCES FROM BRINE SOLUTION. Food grade salt is one kind of salts controlled by imported products. For substitution of imported was needed to developed of salt production process of the salt at Indonesia. In this research was studied to production of food grade salt by crystallization process using brine solution from waste of pharmaceutical grade salt production process. The result of food grade salt by qualitative test including flame test, natrium ion test, chloride ion test, solubility test, crystal shape test by microscopy, and pattern of XRD difractogram have shown a symilar data with MSDS of $\mathrm{NaCl}$. The result of study shown that of quality and trace metal contents of the salt which is eligible in terms of quality i.e. $\mathrm{NaCl}$, magnesium, calcium, sulfate, water and heavy metal contents, according to Industrial Ministry Regulation No. 88/M-IND/PER/10/2014.
\end{abstract}

Keywords : Food grade salt, Crystallization, Brine solution, Characterization, Quality

\section{PENDAHULUAN}

Garam aneka pangan merupakan jenis garam yang dibutuhkan oleh industri pangan antara lain industri mie, biskuit, bumbu masak, minuman, mentega, dan kecap. Seperti diketahui kebutuhan beraneka jenis garam Indonesia pada tahun 2015 sudah mencapai 3,6 juta ton terdiri untuk garam industri 2,12 juta ton dan garam konsumsi 1,48 juta ton [1]. Pasokan garam industri Indonesia hingga sekarang masih dipenuhi dari hasil impor. Peruntukkan garam industri antara lain untuk kebutuhan industri kertas, kaca, klor-alkali, pelunakan air, agrokimia dan kimia lainnya 1.500 .000 ton, industri aneka pangan 450.000 ton, industri pengeringan kulit 100.000 ton dan garam farmasi (infus, dialisat, oralit, minuman kesehatan/isotonik) 50.000 ton [1].

Pembagian jenis garam ditentukan oleh kandungan $\mathrm{NaCl}$ dan pengotor utamanya seperti kalsium, magnesium, sulfat, logam barium dan besi. Garam farmasi merupakan garam dengan kualitas tertinggi. Persyaratan 
garam farmasi umumnya merujuk pada Farmakope Indonesia (FI) antara lain kadar $\mathrm{NaCl}>99,0 \%$, kandungan $\mathrm{Ca}$ dan $\mathrm{Mg}<50 \mathrm{ppm}$, sulfat $<150 \mathrm{ppm}$ serta logam berat $<2$ ppm $[2,3]$. Persyaratan kualitas garam aneka pangan tercantum pada Peraturan Menteri Perindustrian RI No. 88/M-IND/PER/10/2014 diantaranya kadar $\mathrm{NaCl}>97 \%$, kadar $\mathrm{Ca}<0,06 \%$, kadar $\mathrm{Mg}<0,06$ $\%$, kadar air $<0,5 \%$, kadar tak larut air $<0,5 \%$ dan kandungan logam Cd, Fe, $\mathrm{Hg}$ [4]. Perkembangan terkini standar kualitas garam aneka pangan sudah tercantum dalam RSNI 8207:2015. Secara rinci data persyaratan kualitas garam pangan konsumsi garam aneka pangan, garam industri CAP dan garam farmasi menurut Peraturan Menteri Perindustrian RI No. 88/M-IND/PER/10/2014, SNI No. 3556-2010 [5] dan FI V ditunjukkan pada Tabel 1.

Besarnya volume impor garam farmasi dan garam aneka pangan setiap tahun akan menyedot devisa negara yang tidak sedikit. Dengan asumsi harga garam industri impor Rp. 600/kg dan garam farmasi impor Rp. 10.000/kg, maka untuk impor kedua garam tersebut dikeluarkan devisa senilai Rp. 570 milyar/tahun.

Tabel 1. Persyaratan kualitas beberapa jenis garam.

\begin{tabular}{lcccc}
\hline & $\begin{array}{c}\text { Garam } \\
\text { konsumsi }\end{array}$ & \multicolumn{3}{c}{ Garam Industri } \\
\cline { 2 - 5 } & $\begin{array}{c}\text { Rumah } \\
\text { Tangga }\end{array}$ & $\begin{array}{c}\text { Industri Aneka } \\
\text { Pangan }\end{array}$ & $\begin{array}{c}\text { Industri } \\
\text { CAP }\end{array}$ & Farmasi \\
\hline NaCl, min \% & 94,0 & 97,0 & 96,0 & 99,0 \\
Ca, maks \% & 1,0 & 0,06 & 0,10 & 0,005 \\
Mg, maks \% & - & 0,06 & 0,05 & - \\
Sulfat, maks \% & 2,0 & - & 0,2 & 0,015 \\
Bahan tak larut, \% & 0,5 & 0,5 & - & - \\
Air, maks, \% & 7,0 & 0,5 & 2,5 & 0,5 \\
Fe(CN)6], ppm & 5,0 & - & - & - \\
Iodium, ppm & $30-40$ & 10 & - & - \\
Cd,ppm & 0,5 & 0,5 & - & - \\
Pb, ppm & 10 & 10 & - & - \\
Hg, ppm & 0,1 & 0,1 & - & - \\
As, ppm & 0,1 & 0,1 & - & 3 \\
Fe, ppm & 100 & - & - & 2 \\
Al, ppm & - & - & - & 0,2 \\
Logam berat, ppm & - & - & - & 5 \\
\hline
\end{tabular}

Oleh karena itu teknologi proses produksi kedua jenis garam tersebut menjadi penting dan harus dikembangkan di Indonesia. Teknologi produksi garam aneka pangan pada skala laboratorium dan skala pilot sudah dikembangkan oleh Badan Pengkajian dan Penerapan Teknologi (BPPT) dengan metode gabungan pemurnian dan kristalisasi bertingkat menggunakan bahan baku garam krosok/kasar [6,7]. Selain itu beberapa penelitian pemurnian garam juga telah dilakukan untuk meningkatkan kualitas garam pada skala laboratorium antara lain dengan proses rekristalisasi bertingkat [8], proses pencucian metode hidro ekstraksi secara batch menggunakan larutan garam jenuh $[9,10]$, proses pengendapan [11,12] dan penggunaan membran HDPE [13]

Untuk memenuhi kebutuhan garam aneka pangan yang masih diimpor, maka diperlukan pengembangan dan penguasaan teknologi produksi garam tersebut di dalam negeri. Hingga saat ini teknologi yang umum digunakan adalah proses pencucian. Penelitian ini bertujuan untuk mengkaji teknologi proses produksi garam aneka pangan alternatif dengan memanfaatan larutan brine sisa proses produksi garam farmasi sebagai bahan baku.

Kebaharuan teknologi proses alternatif ini penggunaan brine tersebut sebagai bahan baku dan sekaligus menjadi produk samping di pabrik garam farmasi. Selain itu mengikuti perkembangan persyaratan kualitas garam aneka pangan yang semakin ketat, maka dalam penelitian ini telah dilakukan pengujian kandungan logam renik serta kualitas garam aneka pangan. Manfaat penelitian ini adalah tersedianya teknologi proses produksi garam aneka pangan alternatif menggunakan bahan baku dalam negeri sehinggga dapat mengurangi volume impor.

\section{METODE PERCOBAAN}

\section{Bahan dan Alat}

Bahan yang digunakan dibagi ke dalam beberapa kelompok yaitu bahan baku dan bahan proses pemurnian serta bahan untuk keperluan analisis. Bahan baku dan bahan proses pemurnian garam farmasi terdiri dari garam kasar kualitas 1 (K1) produksi PT. Garam (Persero), $\mathrm{Na}_{2} \mathrm{CO}_{3}$ kualitas industri (Brataco), $\mathrm{NaOH}$ kualitas industri (Brataco), $\mathrm{HCl} 32 \%$ kualitas industri (Brataco), $\mathrm{BaCl}_{2}$ kualitas industri (Eks China). Sedangkan bahan analisis antara lain $\mathrm{AgNO}_{3}$ p.a (Merck), $\mathrm{NaCl}$ p.a. (Merck), $\mathrm{K}_{2} \mathrm{CrO}_{4}$ p.a (Merck), Na-EDTA p.a. (Merck), indikator EBT (Merck), indikator mureksid (Merck), $\mathrm{HCl} 36 \%$ p.a (Merck), $\mathrm{NaOH}$ p.a. (Merck), indikator brom timol biru (Merck), $\mathrm{NH}_{4} \mathrm{OH}$ pa. (Merck), $\mathrm{NH}_{4} \mathrm{Cl}$ p.a (Merck), $\mathrm{Na}_{2} \mathrm{SO}_{4}$ p.a. (Sidma-Aldrich), $\mathrm{BaCl}_{2}$ p.a. (Merck), dan asam oksalat p.a. (Merck),

Peralatan yang digunakan dalam penelitian antara lain Mikroskop (Zeiss Model Axiovert 40 CFL) untuk mengamati bentuk kristal, Spektrometri XRD (PANalytical B.V) untuk mengamati pola difraksi kristal garam, Neraca Analitik (Precisa) untuk menimbang sampel uji, Moisture Balance (Precisa Model HA 60) untuk penentuan susut pengeringan, Spektrofotometer $U V$-Vis (Thermo Spectronic) untuk menganalisis kandungan sulfat, ICP-EOS (Perkin Elmer) untuk analisis logam renik dan alat gelas umum laboratorium seperti buret, labu volumetrik, pipet volumetrik untuk analisis kadar $\mathrm{NaCl}$ dan pengotor kalsium, magnesium, dan keasaman/kebasaan secara titrasi volumetri.

\section{Cara Kerja}

Produksi garam aneka pangan dalam penelitian ini dilakukan dengan cara proses kristalisasi larutan brine sisa produksi garam farmasi. Larutan brine ini mempunyai kemurnian garam yang tinggi dan kandungan pengotor 
yang lebih rendah karena sudah dilakukan proses pemurnian. Bahan baku untuk produksi garam aneka pangan yang digunakan adalah garam kasar kualitas 1 (K1) produksi PT Garam (Persero) Madura yang kemudian diproses sehingga didapatkan larutan garam murni untuk umpan kristalisasi garam farmasi.

Untuk mendapatkan garam farmasi, proses kristalisasi larutan garam hasil pemurnian dilakukan secara fraksional artinya hanya sebagian larutan yang dikristalkan. Setelah proses pemisahan maka akan di dapatkan larutan brine sisa yang dapat dijadikan bahan baku untuk produksi garam aneka pangan. Bagan proses produksi secara lengkap ditunjukkan pada Gambar 1. Sedangkan kandungan $\mathrm{NaCl}$ dan unsur lainnya pada larutan brine ditunjukkan pada Tabel 2.

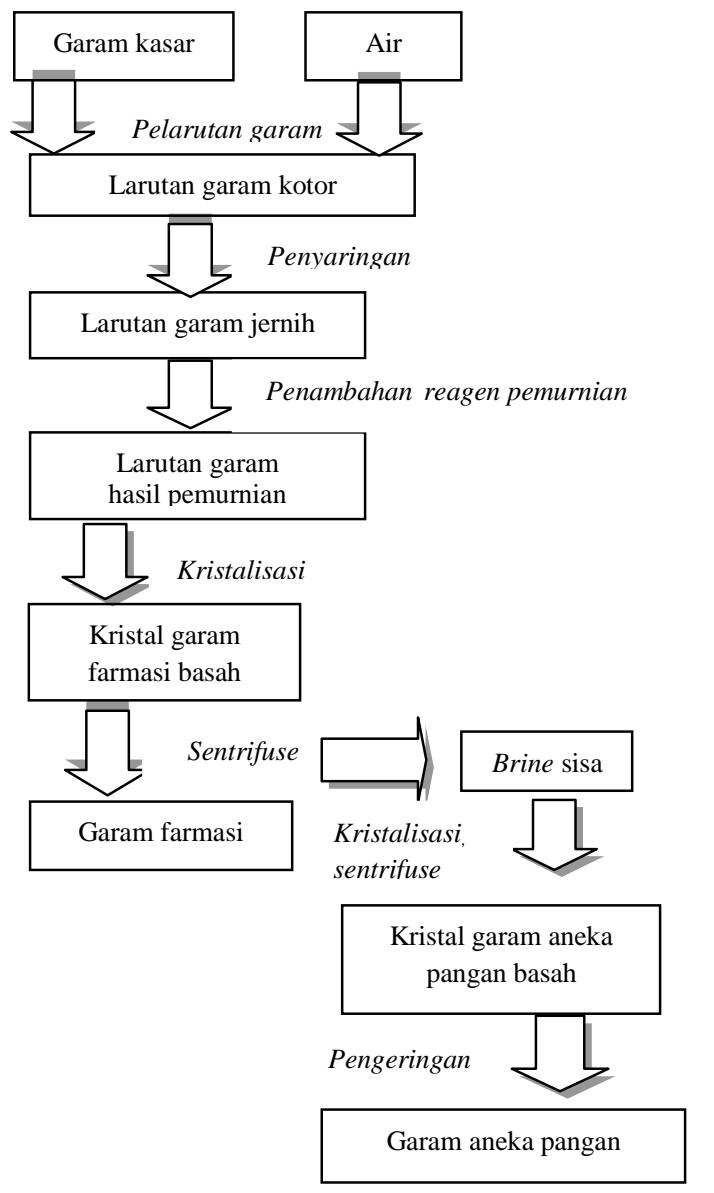

Gambar 1. Diagram proses produksi garam aneka pangan.

Tabel 2. Hasil analisis larutan brine.

\begin{tabular}{lcc}
\hline \multicolumn{1}{c}{ Parameter uji } & Satuan & \multicolumn{1}{c}{ Hasil Uji } \\
\hline Kejernihan & & $\begin{array}{l}\text { Larutan jernih } \\
\text { Positif terhadap uji ion } \\
\text { natrium dan klorida }\end{array}$ \\
Identifikasi & & 360 \\
Kadar $\mathrm{NaCl}$ & gram/liter & $<100$ \\
Ca dan $\mathrm{Mg}$ & $\mathrm{ppm}$ & $<500$ \\
Sulfat & $\mathrm{ppm}$ & 7 \\
$\mathrm{pH}$ & & \\
\hline
\end{tabular}

Pengujian terhadap garam bahan baku dan karakterisasi garam aneka pangan dilakukan di laboratorium PTFM-LAPTIAB, BPPT-Puspiptek dengan mengacu pada prosedur SNI Garam Pangan Konsumsi Berodium No 3556-2010 dan Farmakope Indonesia V, sedangkan analisis beberapa logam renik menggunakan peralatan ICP-EOS dan XRD dilakukan di Laboratorium Geologi, Pusat Survei Geologi, Badan Geologi Kementerian Energi dan Sumber Daya Mineral Bandung. Rendemen hasil produk garam farmasi dan aneka pangan dihitung dengan Persamaan (1).

$$
\text { Rendemen }=\frac{\text { Berat produk garam }}{\text { Berat bahan baku }} \times 100 \% \text {... (1) }
$$

\section{HASIL DAN PEMBAHASAN}

Kualitas bahan baku garam perlu dianalisis untuk menentukan memenuhi persyaratan. Selain itu penentuan kualitas bahan baku terutama kandungan jumlah ion pengotor diperlukan untuk menentukan jumlah bahan kimia yang ditambahkan pada saat proses pemurnian. Hasil analisis kadar $\mathrm{NaCl}$ dan pengotor utama bahan baku garam ditunjukkan pada Tabel 2, sedangkan kandungan garam dan ion lainnya dalam larutan brine ditunjukkan pada Tabel 3.

Tabel 3. Hasil analisis kualitas bahan baku garam kasar.

\begin{tabular}{lcl}
\hline \multicolumn{1}{c}{ Parameter uji } & Satuan & \multicolumn{1}{c}{ Hasil Uji } \\
\hline $\begin{array}{l}\text { Bentuk, warna, rasa } \\
\text { dan penampakan }\end{array}$ & - & $\begin{array}{l}\text { Kristal padat ukuran } \\
\text { sedang sampai besar, } \\
\text { berbentuk kubus, } \\
\text { berwarna putih kusam, } \\
\text { rasa asin }\end{array}$ \\
Lelarutan & & $\begin{array}{l}\text { Larut dalam air, } \\
\text { sebagian kecil bagian } \\
\text { tak larut air, larutan }\end{array}$ \\
& - & $\begin{array}{l}\text { garam keruh } \\
\text { Positif terhadap uji ion } \\
\text { natrium dan klorida }\end{array}$ \\
Identifikasi & & 88,50 \\
Natrium Klorida & & 2.367 \\
(NaCl) & & 818 \\
Kalsium (Ca) & & 1,80 \\
Magnesium $(\mathrm{Mg})$ & ppm & 3,28 \\
Sulfat $\left(\mathrm{SO}_{4}{ }^{2-}\right)$ & ppm & 0,50 \\
Kadar air & $\%$ & 0,045 \\
Kadar tidak larut air & $\%$ & gram \\
Keasaman & Mek/50 & \\
\hline
\end{tabular}

Hasil pengujian pada Tabel 3. menunjukkan bahwa bahan baku berupa garam kasar K1 mempunyai kadar garam 88,50\%. Hal ini menunjukkan bahwa bahan baku masih mempunyai kualitas di bawah persyaratan kualitas garam konsumsi, sehingga biasanya masih harus dilakukan proses pencucian untuk menjadi garam konsumsi. Kadar $\mathrm{NaCl}$ bahan baku pada Tabel 2 relatif setara dengan kadar $\mathrm{NaCl}$ dari garam hasil produksi petani garam (Tabel 4).

Kadar pengotor berupa kalsium, magnesium dan sulfat adalah rendah bahkan sudah memenuhi spesifikasi 
Tabel 4. Hasil analisis contoh garam rakyat.

\begin{tabular}{lccc}
\hline \multicolumn{1}{c}{ Parameter } & Sampel A & Sampel B & Sampel C \\
\hline Warna & Putih & $\begin{array}{c}\text { Putih } \\
\text { kecoklatan } \\
\text { Kristal besar, }\end{array}$ & $\begin{array}{c}\text { Putih lebih } \\
\text { coklat } \\
\text { Kristal besar, } \\
\text { kubus }\end{array}$ \\
Kejernihan larutan & Jernih & Keruh & Lebih keruh \\
Kadar $\mathrm{NaCl}(\%)$ & 88,68 & 88,29 & 88,13 \\
Kadar air (\%) & 7,24 & 5,45 & 5,81 \\
Kadar Ca (ppm) & 676 & 1.555 & 1.724 \\
Kadar $\mathrm{Mg}(\mathrm{ppm})$ & 8.515 & 7.506 & 3.061 \\
\hline
\end{tabular}

garam konsumsi. Kandungan pengotor tak larut dan air cukup rendah sehingga akan memudahkan dalam pemisahan pengotor saat proses penyaringan untuk mendapatkan larutan garam yang jernih. Kadar keasaman yang rendah menunjukkan bahwa kandungan senyawa anorganik dan organik dalam garam bahan baku adalah rendah dan mungkin ditimbulkan hanya oleh pengotor organik yang tidak larut air.

Untuk produksi garam aneka pangan semakin tinggi kadar $\mathrm{NaCl}$ dan semakin rendah senyawa pengotor kalsium, magnesium dan sulfat akan menguntungkan karena akan semakin sedikit bahan yang diperlukan untuk proses pemurnian dan semakin tinggi rendemen produk yang dihasilkan. Hasil uji kandungan garam pada larutan brine menunjukkan kandungan garam yang tinggi yakni 360 gram/liter serta jumlah pengotor ion kalsium, magnesium, dan sulfat yang rendah, sehingga sangat potensial untuk digunakan sebagai bahan baku produksi garam aneka pangan.

Hasil uji karakterisasi produk garam aneka pangan ditunjukkan pada Tabel 5. Sedangkan Gambar 2 dan Gambar 3 menunjukkan hasil uji pengamatan mikroskopi kristal garam dan pola difraktogram $X R D \mathrm{NaCl}$

Tabel 5. Hasil uji karakterisasi garam aneka pangan.

\begin{tabular}{|c|c|c|}
\hline Parameter uji & Satuan & Hasil Uji \\
\hline $\begin{array}{l}\text { Bentuk, warna, rasa } \\
\text { dan penampakan }\end{array}$ & - & $\begin{array}{l}\text { Serbuk kristal padat, berwarna } \\
\text { putih, rasa asin }\end{array}$ \\
\hline $\begin{array}{l}\text { Pengamatan kristal } \\
\text { dengan mikroskop }\end{array}$ & - & $\begin{array}{l}\text { Kristal berbentuk kubus (lihat } \\
\text { Gambar 2) }\end{array}$ \\
\hline $\begin{array}{l}\text { Pengamatan uji } \\
\text { XRD }\end{array}$ & - & $\begin{array}{l}\text { Difraktogram menunjukkan } \\
\text { puncak pada }{ }^{\circ} 2 \text { tetha }=27,42 ; \\
31,81 ; 45,39 ; 53,94 ; 56,44 \text { dan } \\
66,35 \text { yang identik dengan } \\
\text { puncak difraktogram data base } \\
\mathrm{NaCl} / \text { halite }\end{array}$ \\
\hline Kelarutan & - & $\begin{array}{l}\text { Mudah larut dalam air, larut } \\
\text { sempurna, larutan jernih. }\end{array}$ \\
\hline $\begin{array}{l}\text { Identifikasi reaksi } \\
\text { nyala }\end{array}$ & - & $\begin{array}{l}\text { Positif terhadap reaksi nyala uji } \\
\text { natrium dengan timbulnya warna } \\
\text { kuning }\end{array}$ \\
\hline $\begin{array}{l}\text { Uji reaksi ion } \\
\text { natrium }\end{array}$ & - & $\begin{array}{l}\text { Positif terhadap reaksi dengan } \\
\text { pereaksi kobal uranil asetat, } \\
\text { terbentuk endapan berwarna } \\
\text { kuning keemasan }\end{array}$ \\
\hline $\begin{array}{l}\text { Uji reaksi ion } \\
\text { klorida }\end{array}$ & - & $\begin{array}{l}\text { Positif uji dengan larutan perak } \\
\text { nitrat LP, terbentuk endapan putih } \\
\text { yang tidak larut dalam asam nitrat } \\
\text { pekat }(\mathrm{P}) \text {, tetapi larut dalam } \\
\text { larutan amonium hidroksida } 6 \mathrm{~N} \\
\text { berlebih }\end{array}$ \\
\hline
\end{tabular}

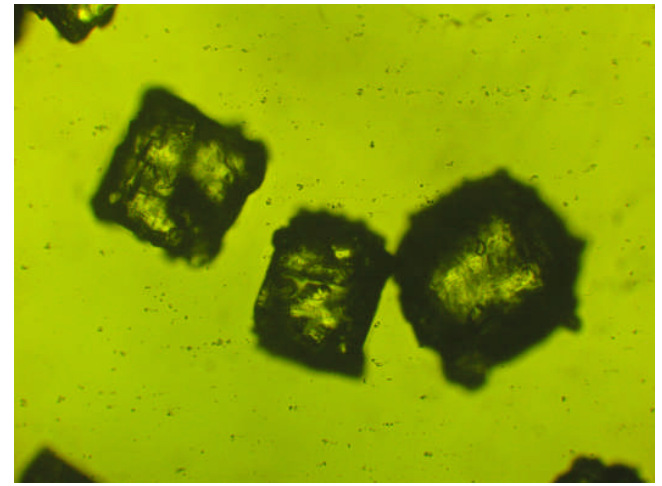

Gambar 2. Bentuk kristal garam aneka pangan hasil pengamatan mikroskop pada perbesaran $400 \mathrm{X}$ menggunakan mikroskop Zeiss Model Axiovert $40 \mathrm{CFL}$
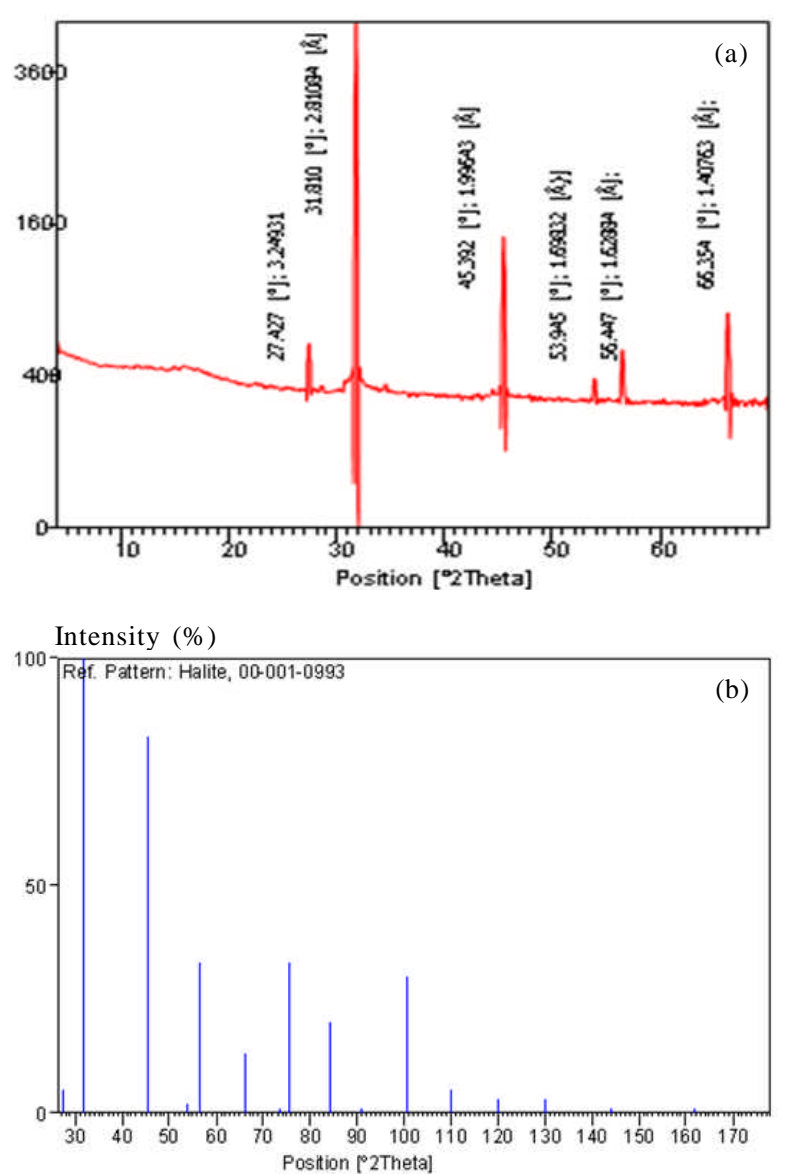

Gambar 3. Difraktogram garam aneka pangan (a) dan pola difraktogram database $\mathrm{NaCl}$ (b), berdasarkan pustaka Hanawalt et al., Anal. Chem., 10, 475, (1938) dan data optik Chem. for Cer. Use, Natl. Res. Council Bull. 107) Ref Code : 00-001-0993.

yang dinalisis menggunakan sinar $\mathrm{Cu}-\alpha$ pada panjang gelombang 1,54 Amstrong.

Hasil karakterisasi uji kualitatif dengan reaksi nyala, uji identifikasi ion natrium dan klorida, uji kelarutan pada Tabel 5 menunjukkan bahwa kristal garam aneka pangan yang terbentuk adalah $\mathrm{NaCl}$. Hal ini juga didukung dari pengamatan bentuk kristal secara miksrokop yakni kristal berbentuk kubus dan pola 
difraktogram $X R D$ garam aneka pangan yang identik dengan kristal $\mathrm{NaCl}$.

Hasil analisis terhadap kualitas garam aneka pangan hasil kristalisasi ditunjukkan pada Tabel 6. Sedangkan gambar bahan baku garam dan produk garam aneka pangan yang dihasilkan ditunjukkan pada Gambar 4. Kualitas garam aneka pangan yang diproduksi sudah memenuhi persyaratan SNI dan Peraturan Menteri Perindustrian ditinjau dari parameter utama seperti kadar $\mathrm{NaCl}$, kandungan kalsium, magnesium, sulfat, dan kadar air. Hasil uji menunjukkan bahwa kadar garam aneka pangan yang dihasilkan adalah lebih baik bila dibandingkan dengan hasil penelitian yang masingmasing menghasilkan garam dengan kadar $\mathrm{NaCl}$ $99,01 \%$ dan kadar tak larut air 0,82\% [8], kadar $\mathrm{NaCl}$ $90,98 \%$ (pemurnian dengan natrium oksala-bikarbonat) dan $96,40 \%$ (pemurnian natrium oksalat-karbonat) [11].

Tabel 6. Analisis kualitas garam aneka pangan.

\begin{tabular}{lcc}
\hline \multicolumn{1}{c}{ Parameter uji } & Satuan & Hasil Uji \\
\hline $\mathrm{NaCl}$ & $\%$ & 99,83 \\
Kalsium $(\mathrm{Ca})$ & $\mathrm{ppm}$ & Tidak terdeteksi \\
Magnesium $(\mathrm{Mg})$ & $\mathrm{ppm}$ & 2,74 \\
Sulfat $\left(\mathrm{SO}_{4}{ }^{2-}\right.$ & $\%$ & $<0,2$ \\
Keasaman/kebasaan & $\mathrm{Mek} / 50$ gram & 0,1070 \\
Kadar tidak larut air & $\%$ & 0 \\
Susut Pengeringan & $\%$ & 0,20 \\
Iodida/Bromida & - & Negatif \\
Fe(CN)6- & - & Negatif \\
Iodium & - & Negatif \\
\hline
\end{tabular}
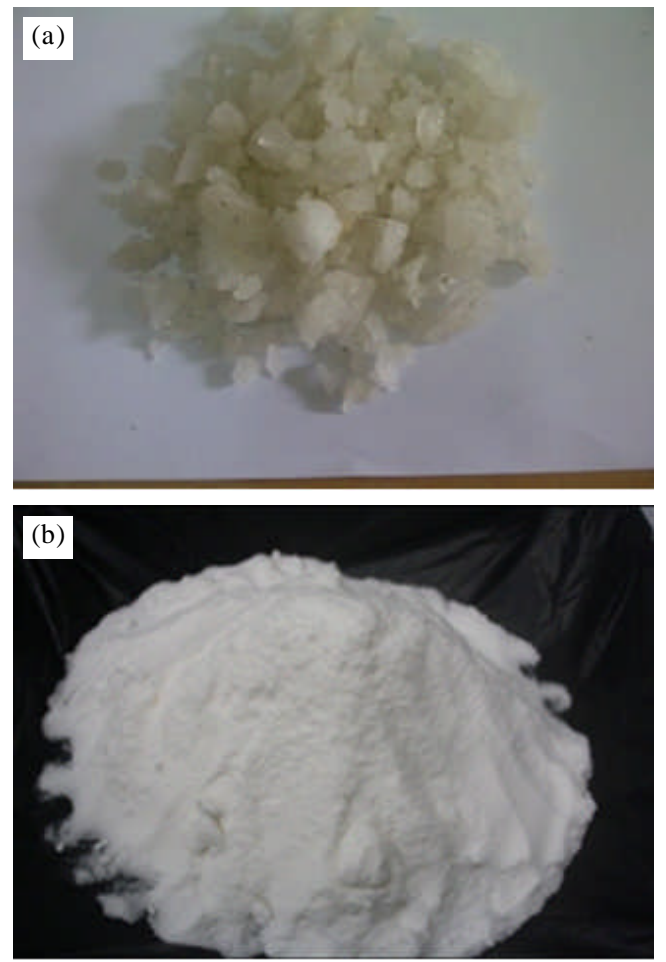

Gambar 4. (a). Bahan baku dan (b). produk garam aneka pangan.

Produk garam aneka pangan bila dibandingkan dengan hasil penelitian kualitas garam farmasi oleh tim PTFM-BPPT menunjukkan kualitas yang hampir sama dan memenuhi persyaratan FI V, kecuali angka keasaman $[14,15]$.

Selain pengujian kualitas yang meliputi kadar dan pengotor utama, terhadap bahan baku dan garam aneka pangan juga telah dilakukan pengujian kandungan logam renik. Hasil pengukuran logam renik ditunjukkan pada Tabel 7.

Tabel 7. Hasil analisa logam renik bahan baku dan garam aneka pangan.

\begin{tabular}{cccc}
\hline $\begin{array}{c}\text { Lenis } \\
\text { Logam }\end{array}$ & $\begin{array}{c}\text { Dalam garam } \\
\text { aneka pangan } \\
\text { (ppm) }\end{array}$ & $\begin{array}{c}\text { Dalam } \\
\text { bahan baku garam } \\
(\mathrm{ppm})\end{array}$ & $\begin{array}{c}\text { Batas Deteksi } \\
\text { ICP }- \text { OES } \\
(\mathrm{ppm})\end{array}$ \\
\hline $\mathrm{Al}$ & t.d & 1 & 1 \\
$\mathrm{As}$ & t.d & t.d & 1 \\
$\mathrm{Ca}$ & t.d & 2.367 & 1 \\
$\mathrm{Cd}$ & t.d & t.d & 1 \\
$\mathrm{Co}$ & t.d & t.d & 1 \\
$\mathrm{Cr}$ & t.d & t.d & 1 \\
$\mathrm{Cu}$ & t.d & t.d & 1 \\
$\mathrm{Fe}$ & t.d & 1 & 1 \\
$\mathrm{~K}$ & 943 & 1.118 & 1 \\
$\mathrm{Li}$ & 0,1 & 0,1 & 0,1 \\
$\mathrm{Mg}$ & 0,3 & 818,9 & 0,3 \\
$\mathrm{Mn}$ & t.d & 1 & 1 \\
$\mathrm{Ni}$ & t.d & t.d & 1 \\
$\mathrm{~Pb}$ & t.d & t.d & 1 \\
$\mathrm{Sb}$ & t.d & t.d & 1 \\
$\mathrm{Sr}$ & t.d & 22,9 & 0,1 \\
$\mathrm{Zn}$ & 0,2 & t.d & 0,1 \\
\hline
\end{tabular}

Hasil menunjukkan bahwa secara umum logam renik dalam bahan baku adalah kecil bahkan tidak dapat terdeteksi sesuai batas deteksi alat ICP-EOS untuk masing-masing logam, sehingga baik digunakan sebagai bahan baku. Kecilnya kandungan atau tidak terdeteksinya kandungan logam renik terutama diakibatkan oleh adanya proses pengendapan beberapa logam pada saat proses pembuatan garam kasar di ladang pegaraman. Hal ini dapat dilihat dari hasil penelitian yang dilakukan terhadap penentuan kadar logam dalam air laut yang umumnya lebih besar dibandingkan kandungan yang ada dalam garamnya

Kadar logam yang cukup tinggi selain kandungan kalsium dan magnesium adalah logam kalium dan stronsium. Hal ini disebabkan kedua logam tersebut sedikit sekali terpisah saat pembuatan garam. Tetapi secara hasil analisis logam renik pada bahan baku garam menunjukkan bahwa bahan baku dan air laut di sekitar Pulau Madura (sesuai lokasi ladang pegaraman bahan baku PT. Garam) masih dalam kondisi baik atau belum terkontaminasi oleh logam-logam berbahaya.

Hasil uji logam renik pada produk garam aneka pangan juga menunjukkan hasil yang baik, yakni tidak terkandungnya logam-logam berbahaya. Beberapa logam yang terkandung dalam bahan baku dapat dihilangkan atau diturunkan kadarnya, terutama kandungan kalsium dan magnesium. Hal ini berarti proses pemurnian dan kristalisasi pada proses pembuatan garam aneka pangan dapat mengeliminasi beberapa logam renik. Sedangkan 
adanya logam seng diduga karena ada pengotor dari peralatan atau reagent, tetapi hal ini masih di bawah ambang batas yang dipersyaratkan.

Bila dibandingkan dengan proses produksi garam aneka pangan yang digunakan di Indonesia sekarang ini yakni menggunakan proses pencucian garam industri (asal impor) dengan larutan garam jenuh, maka produksi garam aneka pangan dalam penelitian ini memerlukan biaya sedikit lebih besar, terutama untuk biaya proses pemurnian dan kristalisasi. Oleh karena itu, ditinjau dari segi keekonomian pembangunan unit produksi garam pangan disarankan merupakan bagian dari unit produksi garam farmasi, terutama untuk menekan biaya produksi sehingga pabrik bisa mendapatkan keuntungan. Hal ini terutama dalam efisiensi penggunaan peralatan proses dan pemanfaatan larutan brine sisa. Hasil kajian juga menunjukkan bahwa rendemen garam farmasi dan garam pangan hasil proses kristalisasi masing-masing adalah $50-55 \%$ dan $20-25 \%$.

\section{KESIMPULAN}

Karakterisasi terhadap garam aneka pangan menunjukkan bahwa kristal yang terbentuk adalah $\mathrm{NaCl}$. Hasil uji kualitas dan kandungan logam renik menunjukkan bahwa garam aneka pangan yang diproduksi dari proses kristalisasi larutan brine sisa produksi garam farmasi sudah memenuhi persyaratan kualitas garam aneka pangan sesuai Peraturan Menteri Perindustrian RI No. 88/M-IND/PER/10/2014. Aplikasi teknologi proses produksi garam aneka pangan pada skala industri hendaknya harus satu paket dengan pabrik garam farmasi terutama untuk efisiensi penggunaan peralatan proses, pemanfaatan larutan brine sisa dan sekaligus untuk menekan biaya produksi sehingga dapat layak secara ekonomi.

\section{UCAPAN TERIMAKASIH}

Disampaikan kepada Laboratorium Geologi, Pusat Survei Geologi, Badan Geologi-Kementerian Energi dan Sumber Daya Mineral-Bandung atas bantuan dan kerjasamanya dalam analisis logam renik dan karakterisasi menggunakan peralatan ICP-EOS dan XRD.

\section{DAFTAR ACUAN}

[1]. Kementerian Kelautan dan Perikanan, Analisis Produksi Garam, 2015

[2]. Departemen Kesehatan Republik Indonesia, Farmakope Indonesia, Edisi V, 2015

[3]. Departemen Kesehatan Republik Indonesia, Suplemen I - Farmakope Indonesia, Edisi V, 2015

[4]. Peraturan Menteri Perindustrian RI No. 88/M-IND/ PER/10/2014, "Perubahan atas Peraturan Menteri Perindustrian No : 134/M-IND/PER/10/2009 tentang Peta Panduan (Road Map) Pengembangan Klaster Industri Garam, 2014.

[5]. SNI Garam Pangan Konsumsi No 3556, 2010.

[6]. E. Rismana, Nizar. "Kajian Produksi Garam Aneka Pangan dari Beberapa Sumber Bahan Baku." Chemical Progress - Unsrat, vol. 7, no. 1, pp. 25 - 28, Mei 2014.

[7]. E. Rismana, B. Srijanto. "Pengembangan Teknologi Produksi Garam Farmasi dan Aneka Pangan di BPPT." Lokakarya Nasional "Indonesia Menyongsong Swasembada Garam Industri 2015.", Pusat Penelitian Sains dan Teknologi Universitas Indonesia - UI, 24 April 2013.

[8]. L. Nurhidayati. "Peningkatan Kualitas Natrium Klorida dari Garam Dapur Melalui Rekristalisasi Bertingkat." Seminar Nasional Kimia 2007, Universitas Indonesia, 7 - 8 Agustus 2007.

[9]. A.Martina, J. R. Witono. "Pemurnian Garam dengan Metode Hidro Ekstraksi Sistem Batch.” LPPM UK Parahyangan, 2014.

[10]. A. Martina, J. R. Witono, G. K. Pamungkas, Willy. "Pengaruh Kualitas Bahan Baku dan Rasio Umpan Terhadap Pelarut Pada Proses Pemurnian Garam Dengan Metode Hidroekstraksi Batch.” Jurnal Teknik Kimia USU, vol. 5, no. 1, Maret 2016.

[11]. T. Sulistyaningsih, W. Sugiyo, S. M. R. Sedyawati. "Pemurnian Garam Dapur Melalui Metode Kristalisasi Air Tua dengan Bahan Pengikat Pengotor $\mathrm{Na}_{2} \mathrm{C}_{2} \mathrm{O}_{4}-\mathrm{NaHCO}_{3}$ dan $\mathrm{Na}_{2} \mathrm{C}_{2} \mathrm{O}_{4}-\mathrm{Na}_{2} \mathrm{CO}_{3}$." Jurnal Sains dan Teknologi, No. 8, vol. 1, pp. 26-33, 2010.

[12]. D. D. T Rathnayaka, P. W. Vidanage, K. C. Wasalathilake, H. W. Wickramasingha, U. P. L. Wijayarathne, S. A. S. Perera. "Development of a Process to Manufacture High Quality Refined Salt from Crude Solar Salt.” World Academy of Science, Engineering and Technology International Journal of Chemical, Molecular, Nuclear, Materials and Metallurgical Engineering, vol. 7, no. 12, 2013.

[13]. Rusiyanto, E. Soesilowati, Jumaeri. "Penguatan Industri Garam Nasional Melalui Perbaikan Teknologi Budidaya dan Diversifikasi Produk." Jurnal Sains dan Teknologi, vol. 11, no. 2, Desember 2013.

[14]. BPPT Enjiniring-Kemenkes RI. "Pembuatan Produk Contoh Garam Farmasi Skala Laboratorium." Laporan Kegiatan, 2012.

[15]. E. Rismana. "Pengujian Cemaran Bakteri, Kapang, dan Khamir di Unit Produksi Garam Farmasi Skala Pilot Kapasitas 5 Kg/Batch", Media Penelitian dan Pengembangan Kesehatan, vol. 26, no. 1, pp. 29-36, Maret 2016. 